Kohl: a Journal for Body and Gender Research

Vol. 2, No. 2 (Winter 2016)

\title{
Migrating to the Lebanese Civil War
}

Mala

Edited by Ghiwa Sayegh

This oral testimony was part of a recorded conversation between migrant domestic workers living in Lebanon. 
When I sought work outside of Sri Lanka, my agency sent me to Cyprus, and I assumed that I would work there. When I arrived in Cyprus, I was taken to the seaport where I stayed for a whole day with no food. At nighttime, they put me in a boat with other migrant workers. In the middle of the sea, they put every six of us in smaller boats, and we arrived to Beirut's port under the bombings. That was in 1983, during the Lebanese Civil War.

I had reached Cyprus on the $24^{\text {th }}$ of May, and Beirut on the $26^{\text {th }}$. I stayed at the Lebanese agency for two days. On the $28^{\text {th }}$ of the month, my "madam" 1 finally came for me and took me to her house. I had long hair back then. Upon arrival, she cut off my hair, undressed me, then put all of my clothes in one zbele kees, ${ }^{2}$ and threw it away. She mixed Dettol with the bathtub water, handed me a bar soap, and watched me take my bath. Then, while I was still naked, she ordered me to clean the bathroom. I was very cold, so I cleaned after myself while shivering. She then told me to go to my room, put some clothes on, and start working.

I stayed with that "madam" for a year and nine months. She did not give me my salary at the end of every month. She kept saying that the bank was closed and that she could not wire money to my country. I was left penniless for four months. One day, she told me that she could not pay me in dollars, but would give me 1,000 liras $^{3}$ instead. I said no. I did not want her to pay me in Lebanese Liras. I had come to Lebanon for my children. I left them in Sri Lanka for the money, so I wanted my 100\$, not 250 liras. I told her I would only continue working for her if she gave me all my salaries in dollars. She said to me: "do your work and l'll give you your money." But she didn't, and I was unable to send money home. I refused to work, locking myself up in my room.

The family had four children. I cooked, cleaned, and took care of the children all day long. When the parents were out, the children stayed under my care. The "madam" was very nice, she taught me everything about domestic work. If I ran out of milk at night, she would go out and buy some more because she knew I drank a glass of milk every morning before starting to work. I had so much work that I could not have breakfast, and sometimes would not eat anything until lunch. As I was the one cooking for the entire family, she also never locked the fridge. She gave me food whenever they ate and kept the fridge accessible. I knew that in my building, some families locked their fridge with a key so that the girls ${ }^{4}$ could not eat one khebez piece ${ }^{5}$ more than what they were given. She did not have too much clothes to give me. I had brought two outfits back from Sri Lanka with me, and she provided me with two uniforms. That was all I had for a year and nine months, but it was not a problem for me - money was the only issue. She said she had four children who needed to study, but I had children as well, and I had left them behind.

\footnotetext{
1 "Madam" is the term migrant domestic workers are asked to use to refer to their employers. Employers are rarely called by their names.

2 Trash bag

3 The equivalent of $400 \$$ in Lebanese currency before it was devalued.

${ }^{4}$ Migrant domestic workers are referred to as "girls."

5 Piece of bread.
} 
Very few letters came from Sri Lanka. It was during the Civil War, so we received mail every six months. When I boycotted work because she was not paying me, she did not say anything for the first couple of days. I then called the agency and told them I did not want to work for her anymore, so she took me to the agency's office. There, she gave the equivalent of what she was supposed to pay me to the agency man, in addition to my plan ticket fees. The agency man beat me up twice, but I refused to go back. I still had $300 \$$ with me from the first months of work - the amount was still with me because I could not leave the house to put it in a bank or transfer it to my children. He took everything I had and said: "here is your passport, now leave."

In a few occasions, I had taken my first "madam's" children to a woman in a neighboring street to where the family used to live. I called her and told her I wanted to work for her. She sent me a taxi, and I have been working for her ever since. I could also work for other families in my free time, so I started working part-time in another household. I used to get paid 150 liras for every week's work, and even while the currency was being devalued, I could not negotiate the price because I had lost too much.

Working in a foreign country torn by a war was extremely hard. Under the bombs, you do not know when your time comes. I spent a few years running away from the bombs: when there were bombings in Beirut, we would run to the mountains. Then the bombings would start in the mountains, so we would go back to Beirut. Sometimes, while escaping, we could hear the bombs over us. I did not know where or when I would die, but death seemed imminent. I remember that time when I was going back to the "madam's" house, and a bomb exploded right in front of me. It passed above my head and hit a house not too far from where I was. I saw it with my own eyes. I could not feel my body, but I ran home, my clothes covered in my own pee. I ran because my children needed me. I had to save my life so they could still receive my salary and pursue their studies. For two years, we slept in the basement. I would work, clean, cook during the day, then at nightfall, all the Lebanese families and myself would sleep in the basement. I never slept well during those long nights. During the day, I did not have time to think, as I had to work and fulfill the demands of my "madam." But at night, I thought of how I cooked for other women's children, and wondered whether my own children were eating.

After a while, I stopped working outside, ${ }^{6}$ as a freelancer. I stayed with my "madam" and worked for her, but I would visit Sri Lanka every two years. Then, I started cooking only and they brought another girl as my "madam" got a bit sick. I cooked, left the food at home, and when I was free, I would go around neighboring houses and work hard. It was too little for me to have only one salary with four children studying back home, their needs becoming more and more pressing as they grew up away from me. Working outside is a very hard life, so I wanted to do something for girls like me to help each other. I have worked a lot with the Migrant Community Center, Insan, Kafa, and other organizations. I wanted migrant domestic workers to work together and support each other, so I started a women society. With the support of my sisters, life became a bit easier in Lebanon.

\footnotetext{
${ }^{6}$ For migrant domestic workers, working "outside" means not living with and working for a single family. Instead, they rent their own rooms and work per hour in many houses.
} 